\title{
渡邊昇先生との思い出
}

遠藤 康夫

（東北大学名誉教授，高エネ研ダイヤモンドフェロー）

\section{A Short Memory with Professor Noboru Watanabe}

Yasuo Endoh

Diamond Fellow, KEK

\section{0 \\ 000000}

\begin{abstract}
Short memories or a few episodes with the Professor Noboru Watanabe are presented in order to condole his death.

Keywords: Nuclear Science Laboratory, Tohoku University, KENS Facility of KEK, Japan-UK collaboration program
\end{abstract}

渡邊昇先生のご逝去の訃報に接し贵心よりお 悔やみ申し上げます. 渡邊先生との交わりは最近 でこそ顔を合わせる機会が稀になったものの, 私 が東北大学物理学科石川研究室に赴任以来実に 45 年以上の長きに亘りました. 療養施設に入ら れてからお目にかかる機会を逸して残念に思っ ておりますが, 長い闘病生活から解放されて今は 安らかにお休みになっていると信じています。

渡邊先生の東北大学時代は苦労の連続であっ たでしょう.工学部在籍時代の事は噂しか知りま せんが，原子核理学研究施設（核理研）に移られ てから木村一治研究室の助手, 助教授として木村 先生の, 木村先生退官後は実質核理研中性子散乱 の中心であった理学部石川義和先生の番頭役を 勤められました。（というのは公式的で聞こえが 良いのですが) 辣腕家の両ボスからの無茶なアイ デアに時には悪戦苦闘されていたのを思い出し ます。核理研は学内共同利用施設とはいえ, 少人 数のスタッフで電子リニアックの運転, 中性子散 乱施設の建設と実験, 寄り合い所带の学生や研究 者の諸々の細かな世話をこなさなければならな い上に, 将来計画構想の立案の重要なメンバーと して寝る暇もないという状況が何年も続きまし た.でもそのような苦境を乗り越えられたのはパ ルス中性子研究の信奉者としてその豊かな将来 性に賭ける熱い情熱であったと思います。

核理研での苦しい一つの思い出があります.石 川研の大学院生の一人が, 中性子源が格納されて いるトーチカ内に取り残されたまま加速器のス イッチが入ったことがありました.まかり間違え ば死者も出かねない事故でしたが, 渡邊先生の機 敏な行動や事故後の適切な対処によって取り返 しのつかない被曝大事故には至りませんでした。
勿論, この事故以後厳重な事故防止策が取られて 2 度と被曝事故は起こりませんでした。渡邊先生 は青葉山の石川研究室に酷く憔悴したお顔を出 されたのを強く記憶しています. 高々 $300 \mathrm{eV}$ の電 子線リニアックの中性子線源から粉末回折, 散漫

(全) 散乱, 高エネルギー中性子による Gd 単結 晶回折など, 当時桁違いに強い原子炉 (JRR2) で出し得なかった研究成果が出されましたし, 東 北大学から次世代に続くパルス中性子研究に携 わる人材を多く輩出した背景には渡邊先生のご 尽力があったからこそです。

高エネルギー研究所 (KEK) ブースターシンク ロトロン利用施設（BSF）の創設と同時に赴任さ れた KEK での渡邊先生はまたも過酷な毎日であ ったと思います. 日常の教官勤務の他にブースタ 一加速器の時間外運転当番とか, 数多くの会議と か, 休む睱なしという生活でよく耐えておられた と驚嘆しておりました. 単身赴任でつくばに滞在 されており, 日常生活はもとより, 偶の仙台の実 家への往復は決まって深夜の自動車運転という 常軌を逸した生活をされていました。「何時死ぬ かわからん大変だ」というのが渡邊先生の口癖で はありましたが，私などは「また始まったか」と その御苦労を見過ごしてしまっていたのは今思 えば不遜で本当に申し訳なかったと後悔してお ります. 渡邊先生どうかお許しください. その時 の思い出話をしましょう。

石川先生が BSF 利用者を集めて日英協力事業 を推進することが決まった年末に (文部省の予算 内示があり) 中性子研究者を集めて研究本館で協 力の要請をする集会を企画されました. 渡邊先生 と私は事前にこの計画構想を聞かされていまし たが, 多くの研究者は初耳であったと記憶してい 
ます.この報告は特に若手を中心に BSF の研究 者にとって唐突なもので，日英協力には素直に賛 同を示さずむしろ反対意見さえ出ました. 極めて 少人数で BSF 管理運営している過酷な日常や, スパレーションパルス中性子散乱の発展時期に 競争相手の ISIS との協力事業などとんでもない というムードがそのような反応の主な理由でし た. 滅多に石川先生の無理難題の注文にも異論を 出されない渡邊先生でさえ日英協力事業の推進 に批判的な意見をのべられました. 私は推進派で したので全く反対意見を述べましたが，集会の後 渡邊先生から「遠藤さんは現場の過酷さをちっと もわかっていない」と苦情をいただき，険亜なム ードになったことを憶えております。

'85 年の早春に石川先生が急逝されました. 西川 KEK 所長は KEK-Rutherford 両研究所の日英協力 事業の推進を残された渡邊先生と私が引継ぐよ うに命令されました. 石川先生の葬儀を終えて余 り時間の立っていない 4 月早々に急遽渡邊先生 と帯同して Rutherford 研究所に向かうことにな りました. 事前の協力事業の交渉は殆ど石川先生 が独自で進められていたので, 我々は俄か勉強を して交渉の場に臨む事になりました. 日英協力事 業の目玉はその後 MARI と名付けたチョッパー 分光器装置の設置でありました. 当時世界中にこ れ程大掛かりなチョッパー分光装置は存在しな かったので世界一のパルス中性子線源に世界一 の性能を持つ非弾性散乱装置の建設というワク ワクした計画であり，しかも日本の資金でイギリ スに建設する物理の世界では画期的な挑戦であ りました. 私はブルックヘブン研究所 (アメリカ) の HFBR に 3 軸中性子分光装置の設置に閒接的 に関与した経験を持ち合わせていたのでこの日 英交渉は規模の違いはあっても大した違いはあ るまいと臨んだのですが, 渡邊先生の緊張は相当 なものでした. 成田からの飛行機の中ではずっと 持ち込んだ書類に目を通し，会談を想定したシミ ユレーションをしておられました. 疲れると席か ら立ち上がって機内をウ口ウ口歩き回り, 休んで おられる様子はなかったようです. 渡邊先生は神 経が細やかで色々な心配事が先ず脳裏に駆け巡 るようです. 想定される問題点に対する回答をあ あでもないこうでもないと思い巡らしておられ たようです。一方，私は何時も通り，時差ボケ防 止の恒例の儀式, すなわち出発後すぐ寝る為のア ルコール摂取に勉めて極めてリラックスしてお りました. 多分渡邊先生は「吞気な奴っちゃなあ」 と呆れていらっしゃったと思います.

Rutherford 研究所での会談は私の想定通り, 最 初 Paul Williams 所長が型通りの挨拶をされまし たが，後は計画の英国側の責任者である Alan Leadbetter 副所長が会議をとり仕切られて, 緊張 気味の渡邊先生に特に気を遣われていました. 実 質的な議論の殆じは彼のオフィスで膝を付き合 わせての会談で, 渡邊先生の心配事は全て杞憂と なって日英協力の船出は順調以上の出発でした.
日本の装置をイギリスに設置するについての法 律的な問題も同行した事務官と先方の法律専門 家を加えた議論の末, 結局イギリスの法律に従う 為に, 建設を予定しているチョッパー分光器の所 有権は Rutherford に帰属する事もその時に凡そ 同意が生まれました。滞在の最後の日の朝, 渡邊 先生と Abingdon の Cosners House の側を流れる Thames の散歩を楽しみましたが，その時の晴れ やかで安堵されたお顔を懷かしく思い出します.

佐々木寛先生の退官後に施設長になられ，BSF 施設の全責任と, 石川先生亡き後のパルス中性子 研究の総指揮官としての重圧は大変のものであ ったと想像します.しかも懸案の将来計画は石川 先生存命の頃の JEMINI（GEMMINI の語呂合わ せ）から原子核や核破砕研究分野を取りこむハド ロン計画への変身など, 所内の他分野との交渉な ど渡邊先生への負担も日増しに増えるばかりで した. その頃, 私は渡邊先生の相談相手を引き受 けることになり, 連日連夜, 電話口で渡邊先生と の議論に明け暮れました。

渡邊先生は KENS II の立ち上げやその後の J-PARC の中性子源, 特にモデレーターの開発な どエンジニアとしての才能を十分に発揮できる 時には迸る情熱を抑えられない位ポジティブに なられますが，心配性の性格からかディレクター という立場で政治的な決断を迫られる事態や他 分野との交渉などは苦手で気の毒になる位ネガ ティヴになられます.私の役目は先ず電話口の向 こうの渡邊先生の泣き言を我慢して聞くことか ら始まります.延々と続く話の結論は大抵私が渡 邊先生の背中を押すことでした. 渡邊先生の何事 にも慎重かつ精確を期す性格の上に, エンジニア 魂を込めて取り組んでこられた成果は今日の J-PARC の中性子線源に結実したことは大変誇ら しいことです。私は身を削って全霊で今日の J-PARC の基礎を築いて来られた渡邊先生の戦友 として長い時期をご一緒できたことを懐かしく 思い出しております.と同時に心残りは渡邊先生 も, 私も政治力や調整力が長けていなかったので 今日の J-PAEC の運営が理想通りには進んでいな いことです。また誠に残念なのは，一度たりとも 真面目な渡邊先生とゆっくり吞み明かした思い 出がないことです.あの世でその機会を作って一 献交わしましょう。 